\title{
Pigment Epithelium Macroadenoma Mimicking Iris or Cilliary Body Melanoma
}

\author{
Sara Sánchez-Tabernero, MD ${ }^{1}$; Ciro García-Alvarez, PhD $^{2}$; Elena García-Lagarto, MD $^{3}$; Maria A Saornil ${ }^{2}$, PhD
}

${ }^{1}$ Department of Ophthalmology, Anterior Segment Service, Moorfields Eye Hospital, London, UK

${ }^{2}$ Servicio de Oftalmología, Unidad de Tumores Intraoculares del Adulto, Hospital Clínico Universitario de Valladolid, Spain

${ }^{3}$ Unidad de Patología, Hospial Clínico Universitario de Valladolid, Spain

ORCID:

Sara Sánchez-Tabernero: http://orcid.org/0000-0003-1745-2890

J Ophthalmic Vis Res 2021; 16 (2): 306-307

\section{PRESENTATION}

A 66-year-old man presented to the Intraocular Tumor Unit at Hospital Clínico Universitario of Valladolid, Spain, with a one-year history of gradual vision loss in the left eye. The patient had previously undergone cataract surgery. Examination revealed a mass arising from the iris, invading the iridocorneal angle and ciliary body, and displacing the intraocular lens posteriorly. The dimensions were $11.51 \times 11.39 \times 7.53 \mathrm{~mm}$, as measured under ultrasound biomicroscopy. The mass was hyperintense on T1- and hypointense on T2-weighed magnetic resonance images. This is the most frequent pattern described in ciliary pigment epithelium adenomas, although hyperintensity on both T1- and T2-weighted images has also been reported. ${ }^{[1]}$ Enucleation was performed because of suspected iris melanoma. Histopathology demonstrated nests and cords of pigmented epithelial cells with an adenoid pattern, consistent with previous studies. ${ }^{[1,2]}$ Atypia, mitotic figures, or infiltrative features were not observed.

Correspondence to:

Sara Sánchez-Tabernero, MD. Department of Ophthalmology, Anterior Segment Service, Moorfields Eye Hospital, 51 North Block, SE1 7PJ London, UK. Email: s.t.sara.g@gmail.com

Received: 08-04-2020 Accepted: 28-09-2020

\section{Access this article online}

Website: https://knepublishing.com/index.php/JOVR DOI: 10.18502/jovr.v16i2.9100
Histopathology was diagnostic of macroadenoma of iris pigment epithelium, although a ciliary body origin could not be excluded.

\section{DISCUSSION}

Histopathology demonstrated nests and cords of pigmented epithelial cells with an adenoid pattern, consistent with previous studies. ${ }^{[1,2]}$ Atypia, mitotic figures, or infiltrative features were not observed.

Histopathology was diagnostic of macroadenoma of iris pigment epithelium, although a ciliary body origin could not be excluded.

\section{Financial Support and Sponsorship}

Nil.

\section{Conflicts of Interest}

The authors declare no interests.

This is an open access journal, and articles are distributed under the terms of the Creative Commons Attribution-NonCommercial-ShareAlike 4.0 License, which allows others to remix, tweak, and build upon the work non-commercially, as long as appropriate credit is given and the new creations are licensed under the identical terms.

How to cite this article: Sánchez-Tabernero S, García-Alvarez C, GarcíaLagarto E, Saornil MA. Pigment Epithelium Macroadenoma Mimicking Iris or Ciliary Body Melanoma. J Ophthalmic Vis Res 2021;16:306-307. 


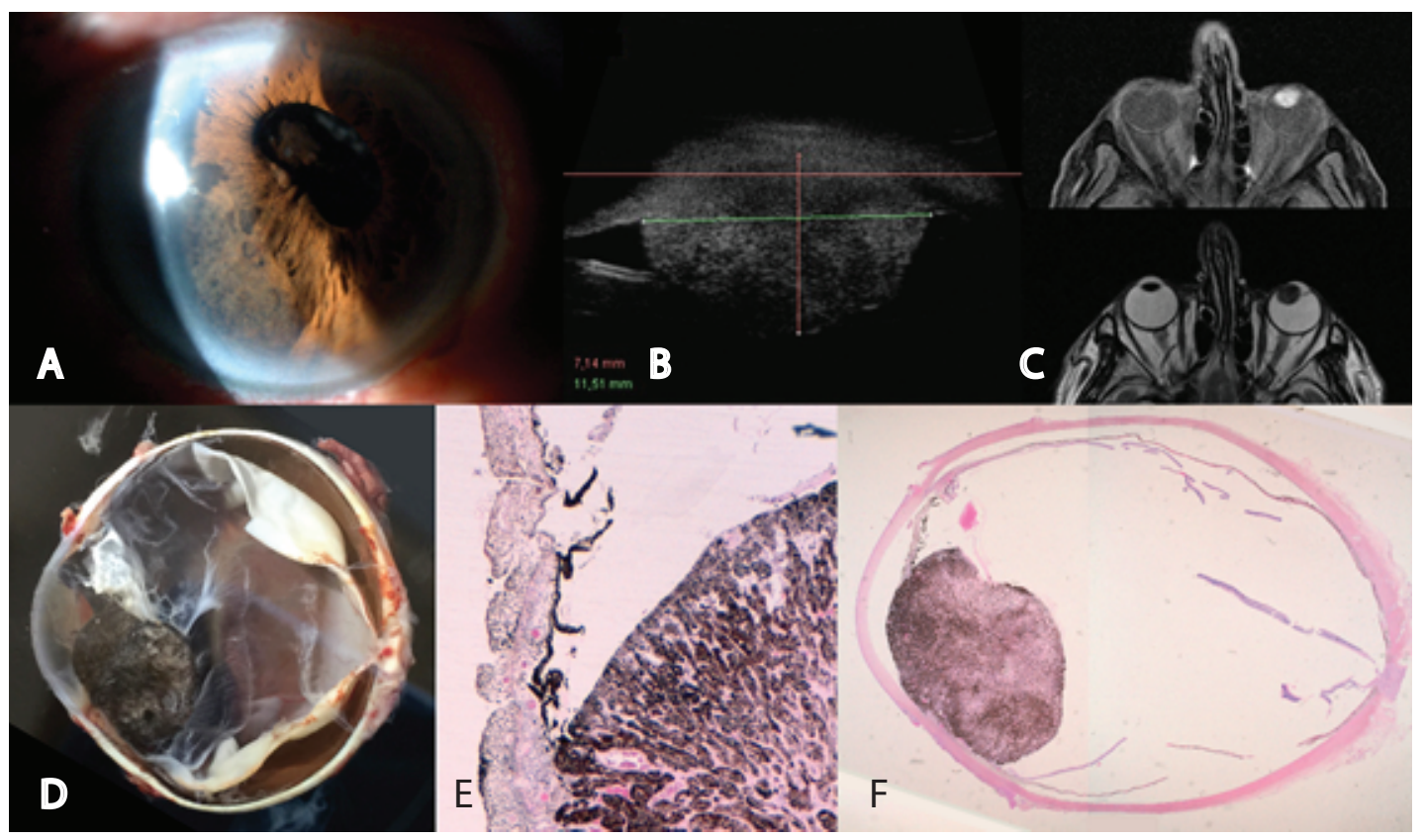

Figure 1. (A) Slit-lamp biomicroscopy showing an iris mass. (B) Ultrasound biomicroscopy. (C) Mass on T1- and T2-weighed magnetic resonance images. (D) Enucleated eye. (E\&F) Hematoxylin and eosin stain, $4 \times$ and low-power magnification.

\section{REFERENCES}

1. Chang Y, Wei WB, Shi JT, Xian JF, Yang WL, Xu XL, et al. Clinical and histopathological features of adenomas of the ciliary pigment epithelium. Acta Ophthalmol 2016;94:e637-e643.

2. Shields JA, Shields CL, Mercado G, Gündüz K, Eagle RC. Adenoma of the iris pigment epithelium: a report of 20 cases. Arch Ophthalmol 1999;117:736-741. 